\title{
VARGA JÚLIA
}

\section{POLITIKAI KÜZDELMEK A SZÁZADFORDULÓN A BUDAPESTI EGYETEMI KÖRBEN $(1888-1899)^{*}$}

\begin{abstract}
Political Struggles at the TuRn of the Century in the UnIVersity CirCle of Budapest 1888-1898. The study presents details about the activities of the, so far quite unknown, University Circle of Budapest in the last decade of the $19^{\text {th }}$ century. Its source is the Egyetemi Lapok university periodical, voicing the political views of the youth. In the writings thereof, the author tries to find sings of how the university students became divided, which manifested itself in the anti-Semitic cross movement in the first year of the new century, in 1901. What led to the principally liberal Hungarian bourgeoisie and gentry youth interested in politics separating itself, or even turning against, their Jewish counterparts, formulating their own interests against them? The Budapest University was one of the prominent locations of the assimilation process of the Jews concentrated in the capital, and the roots of the dividedness of the Hungarian intellectuals may be found in the events, and intellectual reactions, that took place at that time.
\end{abstract}

Tanulmányom célja a budapesti Egyetemi Kör, az egyetemi ifjúság politikai megnyilvánulásai színhelyének bemutatása a 19. század utolsó évtizedében. Forrásomat az egyesület lapja, az Egyetemi Lapok - a hallgatóság politikai véleményének hordozója - képezte. Annak keresem okát az írásokban, hogy hogyan alakult ki az a megosztottság, amely a századforduló első évében, 1901-ben a keresztmozgalom antiszemita megnyilvánulásaiban öltött testet. Mi vezetett oda, hogy az alapvetően liberális magyar polgári-dzsentri politizáló ifjúság elkülönült, sőt szembefordult zsidó társaival, saját érdekeket fogalmazott meg azokkal szemben? Mi a magyarázata annak, hogy az ország másik egyetemén, a kolozsvári egyetemen, valamint több vidéki akadémián antiszemita mozgalomként ítélték meg a budapesti egyetemi ifjúság századfordulós tevékenységét? A budapesti egyetem az egyik kiemelt helyszíne a fóvárosban koncentrálódott zsidóság asszimilációs folyamatának, és az ekkor történt eseményekben, szellemi reagálásokban is kereshetjük a magyar értelmiség megosztottságának gyökereit.

Az egyetemi hallgatóság fogékony korosztály, amelyre hatással volt a korszellem és az új eszmék. Ebben az évtizedben a század uralkodó ideológiája, a liberalizmus már túl van a csúcsponton, a magyar szellemi életben is megjelennek a liberalizmus kritikájaként fellépő eszmeáramlatok, az újkonzervativizmus és a szocializmus. A kor másik nagy eszméje, a nacionalizmus viszont a század végére teljesen meghatározta a magyar politikai és közgondolkodást: célja az egységes magyar nemzetállam megteremtése, a

* Készült az MTA ELTE Egyetemtörténeti Kutatócsoport munkája keretében (213 TKI 738). 
magyar szupremácia fenntartása volt. A dualizmus első felének végére az addig végbement polgárosodási folyamat során megtörtént a magyar uralkodó rétegek kettőssé válása, amikor a szabad gazdasági versenybe bekapcsolódni nem tudó, földjét vesztett magyar, keresztény „„örténelmi” középosztály javarészt az állami bürokráciában helyezkedett el, míg a megvagyonosodott, a zsidóságból kikerült „új”, ipari, kereskedelmi és pénzügyi középosztály érvényesülési területévé a termelési-forgalmi szféra vált. ${ }^{1} \mathrm{~A}$ két réteg nem volt versenytársa egymásnak, hiszen íratlan munkamegosztásban más-más területen dolgoztak. Az Egyetemi Lapokban a diákok írásain keresztül visszatükröződik az a társadalmi folyamat, amelynek során a kialakuló magyar polgárságon belül - amely eredetét tekintve kétféle: a régi, „történelmi” és az „új” középosztály - hatalmi harc zajlik a vezetésért. A küzdelemben a nemesi eredetü, történelmi középosztály diákképviselői az újkonzervatív eszmeáramlatban találják meg azt az ideológiát, amely kifejezi életérzésüket, míg az asszimilált középosztály képviselői ragaszkodnak a liberalizmus ideológiájához, amely ekkorra már veszített erejéből.

Az 1872-ben megalakult Tudomány- és Mủegyetemi Olvasókör volt az első általános egylet, amely összefogta a teljes iffúságot a budapesti egyetemen. A kör azzal a céllal alakult, hogy elősegítse az egyetemi hallgatók társas érintkezését, a hazafiság érzésének ápolását és a tudományos önképzést. Léteztek ezenkívül más funkcióval rendelkező, részérdekeket képviselő egyletek is, például minden fakultásnak volt egy-egy segélyegylete.

A kör alapszabályait az Egyetemi Tanács fogadta el. Tagja lehetett minden egyetemi polgár, aki befizette a 8 korona tagsági díjat. Rendelkezett olvasóteremmel, könyvtárral, társalgóval, játékteremmel, hazai és külföldi lapokat járatott, és tagjai kedvezményesen juthattak hozzá a színház-, fürdő-, báljegyekhez, villamos-, állatkerti, kiállítási és vívómesterjegyekhez, valamint ingyenes gyógykezeléshez a kör orvosainál. ${ }^{2}$

A kör élén az évente választott elnök és a bizottság álltak, ők intézték az ügyeket. A tagok alkotta közgyülés választotta a bizottságot, ez pedig soraiból megválasztotta az elnököt. A bizottság többségét természetesen a győztes párt adta, az ellenzék pedig ún. érdekcsoport-képviselőkön keresztül képviseltette magát. Minden ősszel, szeptember 14-én választási küzdelem zajlott az egyetemen, és a győztes párt vezette abban az évben az Egyetemi Kört. Számtalan leírása található meg az Egyetemi Lapokban az őszi szenvedélyes és lármás választási harcoknak, amelyek általában két párt között, a fehér tollasok és a zöld tollasok között zajlottak. Már két hónappal a tanév vége előtt, április közepén elkezdődtek a választási küzdelmek, a kampány pénzbe került - reklámköltségek, ingyen szivar stb. -, tehát pénztelen diák nem is jelöltethette magát. A korteskedést vállalókat bizottsági tagság illette. A tagok száma az évtized elején elérte a 800-900 föt, ez a teljes egyetemi hallgatóságnak mintegy negyede, de a század végére lecsökkent mintegy 400-500 före.

1 TőKÉczKi László, Történelem, eszmék, politika (Budapest, 1999), 23.

2 Ludwig Rezső és Szemenyei Kornél, Magyar diákélet és diákegyesületek (Budapest, 1900). 
A Tudomány- és Mủegyetemi Olvasókör, amelyet 1891. december 15-től (miután a müegyetemisták kiváltak) Egyetemi Körnek neveznek, képviselte hivatalosan az egyetemi ifjúságot a közéletben, kötelező társadalmi feladatai voltak, például mindig ő szervezte az iffúságot a hazafias ünnepélyeken, mint március 15-e, október 6-a vagy november 1-je, a halottak napja, amikor a nemzet elhunyt nagyjaira emlékeztek. Ekkor érintkeztek a nagyközönséggel, ezenkívül havonta szerveztek matinékat (műsoros rendezvényeket).

Az Egyetemi Körben és lapjában lecsapódott a kor minden eszméje, minden irányzattal foglalkoztak legalább említés szintjén. Az alapszabályok ugyan tiltották a politizálást, de ezt sokféleképpen értelmezték, leginkább azt jelentette, hogy a lap, vagyis az ifjúság ne foglaljon állást napi politikai kérdésekben. Azt természetesnek tekintették, hogy az egyetemi ifjúság, mint a jövő intelligenciája, érdeklődik a közügyek iránt és véleménye van. Sokan a körben való szerepvállalást az igazi politizálás előiskolájának tekintették, ahol fellépést tanultak, tapasztalatokat szerezhettek.

Kezdetben a Tudomány- és Mủegyetemi Olvasókör helyisége az egyetem központi épületében volt, az Egyetem térre nyíló homlokzat egész földszintjét elfoglalta. Az 1887/88-as tanév végén, mivel az egyetemépületet lebontották, az olvasókör a Lipót utca 25. sz. házba költözött. ${ }^{3}$

Az egyetemisták körének vezetése sokáig az arisztokrata származású diákokat is tömörítő dzsentri párt kezében volt. A polgári párt, Degré Miklós pártja első alkalommal 1888-ban győzött, megszerveződésében és győzelmében a polgárság társadalmi térhódítását láthatjuk. Ekkortól számítják a demokrácia megjelenését a körben, az addigi dzsentri klikkuralmával szemben. ${ }^{4} \mathrm{Az}$ ifúság soraiban nincs helye semminemü arisztokráciának, csak a szellem arisztokráciáját ismerik el, egyébként mindenki egyenlő polgára az egyetemnek. ${ }^{5}$ Szerintük nem kell mindenkinek mindenáron egyetemen továbbtanulnia. Jobb lenne a vagyongyarapító polgárok, kereskedők, iparosok számának növelése. ${ }^{6}$

A polgári párt győzelme rövid ideig tartott, a következő évtől ismét a konzervatív párt kezébe került az uralom, de keresték a kiegyezés útját. Eötvös Bálint ${ }^{7}$ megválasztásával 1890-ben azok képviselője került a kör élére, akik elismerték a reform szükségességét, de a mérsékelt, lépésről lépésre haladó reformokét. Eötvös Bálint megreformálta a szakosztályi életet, emelve a színvonalát, és az egyesületi munkával, a hírlapok, a könyvtár, a társalgó fejlesztésével foglalkozott. Közben arról vitáztak a lapban, hogy mi

\footnotetext{
${ }^{3}$ Egyetemi Lapok I. évf. (1888. július 15.) 15-16. sz., 119.

${ }^{4}$ Egyetemi Lapok V. évf. (1892. március 10.) 10. sz., 7-8.

5 Egyetemi Lapok II. évf. (1889. május 5.) 18. sz., 345-346.

${ }^{6}$ Egyetemi Lapok II. évf. (1889. augusztus 1.) 26. sz., 386.

7 Apja, Eötvös Károly országgyűlési képviselő, szépíró, a Függetlenségi és 48-as Párt szellemi irányítója. Lásd http://www.hidasi.hu/index.php?option=com_content\&sectionid=0\&task=view\&id=10\&lang =de\&Itemid= (letöltés: 2018. február 23.).
} 
a demokrácia. A régiek véleménye szerint a reformpárt 1888-as győzelmével bevonult a körbe a „vad demokratismus” szellemisége, és a reform hangzatos jelszava alatt, minden arisztokrata származású ifjút kiraktak a körből, függetlenül attól, hogy tehetséges volt vagy sem. ${ }^{8} \mathrm{Az}$ új, mérsékeltebb vélemény szerint a demokrácia azt jelenti, hogy mindenki olyan helyet foglaljon el a társadalomban, amely őt képességeinél és jelleménél fogva megilleti, ne legyen kizáró ok egy ősi név. Először kerül szóba a munkáskérdés, amely megoldásának szükségességét már felismerték. A szocialisták természetesen túlzó követelésekkel lépnek fel az állammal szemben, amely ezeket mereven visszautasítja. A munkások jobban tennék, ha a szociáldemokrácia túlzott követelései helyett az államra bíznák magukat, amely nem szélsőségesen, társadalmi felfordulást elöidézve, hanem a törvényes rend betartásával fogja rendezni helyzetüket. ${ }^{9}$

A következő években formálódtak, vajúdtak az ifúság szellemi formációi. A régi párt kezében volt a vezetés, de a vezetők mindannyian liberális érzésűek és gondolkodásúak. Későbbi visszaemlékezés szerint az ifjúság két pártja közül az egyik mindig konzervatív, a másik pedig liberális hajlamú volt. Nyíltan, jelszavaiban mind a két párt liberálisnak mondta magát, de - bármilyen kérdésről volt szó - az egyik párt ösztönszerủen hajlott a konzervatív irány felé, a másik meg a liberalizmus nagy jelszavai alatt lépett fel. ${ }^{10}$

A régi párt tagjaként ilyen szabadelvű elnök volt az ügyvéd apával rendelkező Rényi József 1891/92-ben, aki azzal szerzett a közvéleményben nagy tekintélyt és megbecsülést, hogy a magyar egyetemi ifjúság nevében megszervezte a válaszirat megírását a bukaresti diákok magyarellenes memorandumára. Rényi kezdeményezte a hazai ifjúsági egyesületek szövetkezését és az Országos Magyar Diákszövetség létrejöttét. 1892 júniusában hívta össze először Budapestre az egyesületek képviselöit. Szabadelvű nézeteket vallottak a következő egyetemi köri elnökök is, mint Hindy Attila (1892/93) vagy Parcsetich László (1893/94), vezetésük alatt kiegyensúlyozott, nyugodt köri élet folyt.

Az évtized közepétől kikristályosodtak a pártküzdelmek erővonalai, a harc a kialakuló magyar polgári osztályon belül a régiek és az újak vezető szerepéért zajlott. A konzervatív oldalt a dzsentri származású, polgárosuló, míg a liberális oldalt a vezetésben maguknak szerepet követelő zsidó származású ifjúság képviselői foglalják el. Az elkülönülés nem tisztán nemzetiségi alapon történt, konzervatív oldalon is találunk zsidó származásút és liberális oldalon is magyar származású polgárifút, de a tendenciák ebbe az irányba mutattak.

${ }^{8}$ Egyetemi Lapok III. évf. (1890. szeptember 14.) 30. sz., 230.

9 Egyetemi Lapok III. évf. (1890. március 2.) 9. sz., 62-63.

${ }^{10}$ Hindy Attila visszaemlékezése „A pártok” c. tárcájában, lásd Egyetemi Lapok VII. évf. (1894. október 14.) 24. sz., 2-4. 


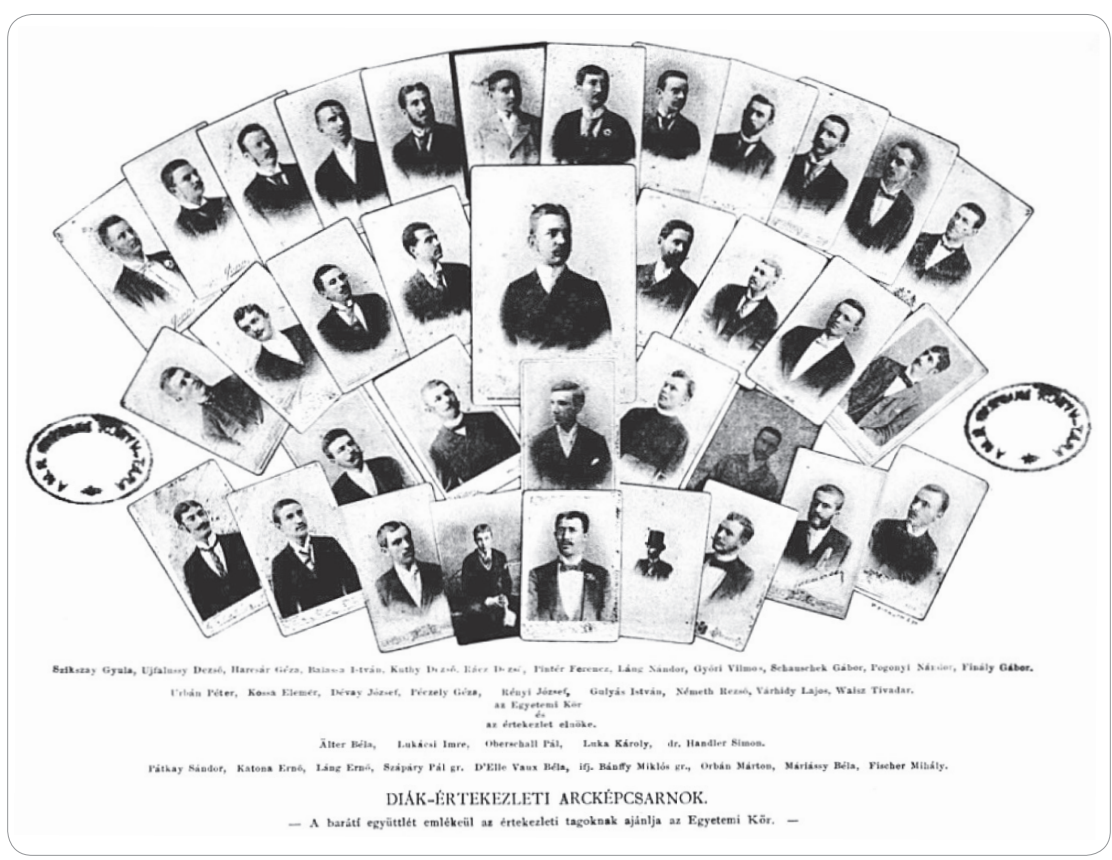

Az elsö, budapesti diákkongresszus résztvevöi 1892-ben

A budapesti egyetemen a zsidó származású hallgatók a század utolsó évtizedében nagy számban képviseltették magukat, a hallgatóság mintegy 30-32\%-át adták. Többségében a jómódú polgári osztályhoz tartoztak, számarányuknál és súlyuknál fogva igényt tartottak az Egyetemi Kör vezetésében való részvételre (lásd a táblázatot).

A budapesti egyetemen még a 80 -as évek elején volt egy antiszemita hullám, ekkor az egyetemi ifúság egy része, mintegy 250 hallgató aláírta az Istóczy Győzőt, az antiszemita párt későbbi létrehozóját üdvözlő iratot. ${ }^{11}$ De ez a vélemény soha nem vált többségi nézetté, főleg az Egyetemi Kör vezetésében. Martos Ferenc, a liberális pártelnök bevallása szerint az Egyetemi Kör bizottságának eleinte határozott szemita jellege volt, ugyanis a zsidó ifjúság szerepet követelt magának a vezetésben és a nyilvánosságban. ${ }^{12}$ A másik nagy egyesület, a Joghallgatók Segítő Egyesülete tömörítette a dzsentri párt konzervatív hallgatóit, ahol az antiszemita gondolkodás is könnyebben elöfordult. Az Egyetemi Lapok, a kör hivatalos orgánuma mindig elítélően nyilatkozott a külföldön, a berlini vagy bécsi egyetemen történt antiszemita esetekről. ${ }^{13}$

${ }^{11}$ SzABó Miklós, Az újkonzervativizmus és a jobboldali radikalizmus története (1867-1918) (Budapest, 2003), 111.

12 Egyetemi Lapok VII. évf. (1894. december 9.) 32. sz., 1-3.

13 Egyetemi Lapok IV. évf. (1891. márc. 29.) 13. sz., 106; VI. évf. (1893. ápr. 16.) 10-11. sz., 8; VI. évf. (1893. május 14.) 15. sz., 5; VIII. évf. (1895. január 13.) 2. sz., 6-7. 
A zsidó származású diákok aránya a budapesti egyetemen ${ }^{14}$

\begin{tabular}{|l|l|c|c|c|c|}
\hline \multicolumn{1}{|c|}{ Tanév } & \multicolumn{2}{c|}{ Rektor } & \multicolumn{2}{c|}{ Összes } & \multicolumn{2}{c|}{ Izraelita } \\
\hline & & I. & II. & I. & II. \\
\hline $1887 / 88$ & Hunfalvy János & 3671 & 3370 & $1135(31 \%)$ & $1061(31 \%)$ \\
\hline $1888 / 89$ & Klinger István & 3441 & 3244 & $1175(34 \%)$ & $1118(34 \%)$ \\
\hline $1889 / 90$ & Hajnik Imre & 3338 & 3178 & $1119(34 \%)$ & $1072(34 \%)$ \\
\hline $1890 / 91$ & Schulek Vilmos & 3305 & 3200 & $1133(34 \%)$ & $1091(34 \%)$ \\
\hline $1891 / 92$ & Eötvös Loránd & 3286 & 3008 & $1121(34 \%)$ & $1001(33 \%)$ \\
\hline $1892 / 93$ & Breznay Béla & 3255 & 3004 & $1038(32 \%)$ & $999(33 \%)$ \\
\hline $1893 / 94$ & Schrnierer Aladár & 3453 & 3142 & $1083(31 \%)$ & $992(32 \%)$ \\
\hline $1894 / 95$ & Fodor József & 3639 & 3306 & $1153(32 \%)$ & $1043(32 \%)$ \\
\hline $1895 / 96$ & Lengyel Béla & 3877 & 3623 & $1236(32 \%)$ & $1158(32 \%)$ \\
\hline $1896 / 97$ & Bognár István & 4621 & 4217 & $1385(30 \%)$ & $1259(30 \%)$ \\
\hline $1897 / 98$ & Herczeg Mihály & 4284 & 3934 & $1288(30 \%)$ & $1177(30 \%)$ \\
\hline $1898 / 99$ & Mihalkovics Géza & 5382 & 4841 & $1569(29 \%)$ & $1498(31 \%)$ \\
\hline $1899 / 1900$ & Ponori Thewrewk Emil & 5546 & 5009 & $1672(30 \%)$ & $1573(31 \%)$ \\
\hline
\end{tabular}

Az ún. politikai antiszemitizmus akkor jelenik meg az egyetemisták között, amikor észreveszik, hogy bizonyos politikai eseményekre a zsidó származásúak másképpen reagálnak. Két példát hozhatok fel erre. Az egyik eset 1889-ben történt, amikor a francia diákok meghívják Párizsba a magyar diákokat egy nemzetközi diákkongresszusra, abból az alkalomból, hogy megnyitották az új Sorbonne épületét. Elment egy 20 tagú magyar küldöttség, Pichler Győző vezetésével, és az a hír jött vissza, hogy az ajándékba vitt Kossuth-kép átadásánál a magyar ifjak jó része nem volt jelen, azzal az indokkal, hogy ők tartalékos tisztek. Az itthon maradottak ezt árulásnak érezték, a magyarság legszentebb érzései elárulásának, hiszen Kossuth a legnagyobb magyar szabadsághős, aki a magyarok szabadságszeretetének jelképe, nem egy egyszerü forradalmár - ahogy a hatalom láttatni szeretné. A küldöttek pedig előbbre valónak tartották a saját karrierjüket. ${ }^{15}$

A másik példa egy, az Egyetemi Lapokban közölt vitasorozat, amelyet Lázár Béla, a tudományos viták és retorikai esték elnöke robbantott ki azzal az állításával, hogy nem olyan általánosan közkedvelt eszme a Kossuth-kultusz, inkább bosszantja az ifúságot. Nem a fiatalság dolga állást foglalni ebben a kérdésben, ellene vagy mellette tüntetni, turini utakat rendezni, azaz politizálni. Ebben a korszakban, amikor minden megnyilvánulás a nemzeti érzést hivatott kifejezni, ez az állítás „merész” volt. Meg is válaszolják írását vidékről, egy eperjesi és egy nagyváradi akadémista fiatalember szerint egy olyan eszméről van szó, amely minden magyar ifjút megmozgat. Aki Kossuthban csak egy

${ }^{14}$ Az adatok a Rektori beszédekből származnak a vonatkozó évekből.

15 Egyetemi Lapok II. évf. (1889. augusztus 18.) 27. sz., 391-392. 
rég elmúlt korszak feledni nem tudó maradványát látja, az nem is értheti meg az ő nagyságát. Ő egy élő szabadságszobor, az ifúság ideálja, amelyért minden magyar ifú lelkesedik. ${ }^{16}$

Rényi József idejében, 1892-ben megtörtént az első nyílt összetűzés az egyetemisták között, annak kapcsán, hogy üdvözöljék-e Vaszary Kolost hercegprímási címének elnyerése alkalmából. A kezdeményezők szerint Pázmány Péter egyetemalapító utódjáról és egy neves magyar tudósról van szó, az ellenzők felekezeti, tisztán katolikus ügyet láttak benne, és sérelmezték, hogy az üdvözlő deputáció az egész egyetemi ifjúság nevében akar megnyilatkozni. A közgyülésen nyíltan abcúgolta egymást a két csoport: Abzug zsidók! Abzug klerikálisok! - hangzott el. ${ }^{17}$ Végül a többség óhaja szerint üdvözölték a hercegprímást, de például Rényi József, a kör elnöke nem ment el az üdvözlő deputációval. Rényi szerint a zsidókérdésből az csinál ügyet, aki felveti. De az egyetemi ifúság toleranciáját illetően nyugodt, összehasonlítva a külföldi, főleg a német ifúsággal, ahol "gyalázatos" dolgokat művelnek. ${ }^{18}$

A magyarországi fóiskolai hallgatóság támogatta az egyházpolitikai reformokat, a vallásszabadság eszméjét, a zsidóság recepcióját. A budapesti egyetemi ifúság egy díszközgyülésen nyilvánította ki egyetértését a liberális törvényekkel. „Most már semmi akadálya nem lesz annak, hogy egy félmillió, intelligenciája és vagyona által egyaránt kiváló magyar honpolgár teljesen egybeforrhassék a magyar nemzettel." ${ }^{19}$

Az évtized közepén, 1894-ben liberális fordulat történt az Egyetemi Kör vezetésében, amikor a választást Martos Ferenc, a liberális párt elnökjelöltje nyerte meg (1894/95). Ekkorra egyre világosabban elkülönült az ifjúság két vezető csoportja, és egyértelműen magyar-zsidó szembenállássá fejlődött a küzdelmük. Nem az ifúság egészéről beszélünk, nem általános antiszemita érzelmek megnyilvánulásáról, hanem kizárólag a két érdekcsoportról, amelyek az egyetemi ifjúság vezető szerepéért küzdöttek meg egymással. Az egyiket a „Magyar Ifjak Egyesülete” képviselte, a másikat az erre reakcióként létrejött „Liberális Ifjak Egyesülete”. Az egyik bevallottan azért küzdött, hogy az egyetemi ifjúság vezetését méltó - vagyis magyar - kezekbe juttassa. A másik úgy állította be küzdelmét érdeke érvényesítéséért, mintha ez a felvilágosult szellemű magyar ifjúság harca lenne azért, hogy létrejöjjön az „egyenlőség, humanizmus, tolerancia és haladás elvein nyugvó modern Magyarország". ${ }^{20}$

A következő három évben (1895-1897) ismét visszakerült az irányítás konzervatív kézbe (a köri elnökök Komlóssy Arthur, Pálffy Ferenc, Herczeg Béla és Ortmann Albert), és ez idő alatt teljesen kiforrott az újkonzervatív eszmék alapján felállított ideológia, amelyben nagyobb hangsúlyt kapott a nemzeti érzés, a vallásosság. Ők már egy másik generációt képviselnek, mint az előző, amely a liberalizmustól minden jót

${ }^{16}$ Egyetemi Lapok III. évf. (1890. április 20.) 16. sz., 118-119.

17 Egyetemi Lapok IV. évf. (1891. november 15.) 38. sz., 316-317.

${ }_{18}$ Egyetemi Lapok V. évf. (1892. március 10.) 10. sz., 8.

${ }_{19}$ Engel Aurél joghallgató beszéde. Lásd Egyetemi Lapok VI. évf. (1893. november 19.) 32. sz., 5.

${ }^{20}$ Egyetemi Lapok VII. évf. (1894. október 27.) 26. sz., 4. 
várt, számukra kiderült, hogy a liberalizmus a gyakorlatban nem vált be. A konzervatív ifjúság szerint minden liberális korszakot egy konzervatív követ, a liberalizmus, amely egy évszázadon át uralkodott, most el fog bukni, mert kiküszöbölte a valláserkölcsöt, Istent, amihez az embernek a legszentebb érzései füződnek, és ami az állam talpkövét képezi. „A liberalizmus túllőtt a célon, szükség volt arra, hogy a józan elem, a reakció megállítsa.” A konzervativizmus mellett a korszak másik nagy uralkodó eszméje a szocializmus. Melyik fogja követni a liberalizmust? Mind a két eszme az egyénnek a közcél alá rendelését tanítja, csak mások az eszközei, módszerei. Szerintük a konzervativizmus fog győzedelmeskedni, mert a szocializmus csak még jobban felpörgeti a társadalmi forradalmat. A konzervatívok emberbarátsága el fogja oszlatni a liberalizmus egoizmusa által előidézett szociális bajokat. ${ }^{21}$

A lecsúszott dzsentri életérzését fejezi ki Bernát István újkonzervatív közgazdász művének bemutatása: pusztulnak az államfenntartó rétegek - a magyar birtokos osztály és a kisiparosok, kisgazdák. A földbirtokosok fokozottan eladósodtak, a kisiparosok proletárrá és szocialistává lettek. Az internacionális nagytőke hatalomra jutott, a bankok nyereséget könyvelnek el. Az a földbirtokos osztály, amely 1000 évig kezében tartott minden talpalatnyi földet, alig egy fél évszázad alatt úgyszólván megszűnt létezni. Sok tekintetben maga a nemesség is hibás ezért, hiszen épp úgy költekezett, mulatott, mint azelőtt. Mindennek fokmérője a pénz, az eddigi értékek - a hit, a hazafiság - kivesztek. ${ }^{22}$

Ezért szükség lenne ún. nemesi egyesületek alakítására, amelyek célja a magyar nemesi réteg megmentése, vagyis az elszegényedett, tönkrejutott nemes családok sarjainak ösztöndíjak, különféle segítség nyújtása az iskoláztatáshoz, és olyan állás, amely méltó az ősei nevéhez és a társadalomban elfoglalt helyéhez. ${ }^{23}$ Megjelenik tehát a magyar középosztály megteremtésének programja az elszegényedett magyar nemességből.

Burg Kornél zsidó hallgató írásában „objektív” véleményt igyekszik formálni, lévén, hogy mindkét pártnak tagja volt. Az egyikben, a konzervatívban nem tetszett az arisztokratikus vonás, a másikban, a liberálisban a plutokratikus kasztszellem. Mindkét oldal felé kritikusan viszonyul. A Komlóssy-pártról azt állítja, hogy „nem tudja megkülönböztetni a másik oldal liberalizmusában azt, hogy mi az eszme és mi az érdek, $s$ még maga is elhiszi, hogy illiberális". A liberális pártból kiábrándult, mert csak szóban hangoztatta a munkás-diák barátságot, de a gyakorlatban elutasította a megvalósítását. A konzervatívoknál viszont tiszteletre méltónak találja azt, hogy nemzetiek a liberálisok kozmopolitizmusával szemben. A hibájuk is ennek túlzásba vitele. A magyar faj fenntartását, ennek szeparálásával képzelik el. A fajok hivatása viszont a rajtuk kívül álló elemek abszorbeálása. És ha ő és a hozzá hasonlók bejutottak a magyarság sáncaiba, akkor mi joggal zárnának ki mást, aki magyarrá akar lenni. ${ }^{24}$

${ }^{21}$ Egyetemi Lapok IX. évf. (1895. október 3.) 2. sz., 4.

${ }^{22}$ Egyetemi Lapok IX. évf. (1895. október 10.) 3. sz., 5-6.

${ }^{23}$ Egyetemi Lapok IX. évf. (1895. október 17.) 4. sz., 3-4.

${ }^{24}$ Egyetemi Lapok X. évf. (1896. január 25.) 3. sz., 8-9. 
A millennium évére és eseményére való hivatkozással az 1895/96-os tanév második félévében a két párt kibékült, vagyis elhatározta az együtt munkálkodást, és pártállásra való tekintet nélkül elosztották az egyetemi köri bizottsági tisztségeket. Az egyetemi ifjúság egységesen tett eleget a millenniumi ünnepségekben vállalt szerepének, amelyben az egyik legismertebb program a Kecskeméten tartott országos diákkongresszus, valamint a pusztaszeri emlékoszlop leleplezése volt. A Budapesten tartandó nemzetközi diákkongresszust is programtervezetbe vették, de miután a Wlassics Gyula kultuszminisztertől kért segélyt nem kapták meg, a kongresszus megtartása elmaradt. ${ }^{25}$ Ebben az évben költözött a kör ismét új helyiségbe: a Kecskeméti utca 2. sz. alatti Wenckheimházba, az első emeletre, ahol 9 szép szobát kapott. ${ }^{26}$

Az 1896/97-es tanévben nem nagy többséggel Hercegh Bélát, a kolozsvári Egyetemi Kör előző tanévi elnökét választották meg a budapesti kör elnökének. A választást megfellebbezte a vesztes párt. Az Egyetemi Tanács ítéletére, amelyben jóváhagyta a választás eredményét, fellélegzett a győztes párt, amelyből önigazolás tört elő: sok vádaskodást kellett eddig elviseljenek a liberális sajtó részéről, olyan vádakat, amelyeket nem is értenek, például, hogy ők klerikálisok vagy antiszemiták lennének. Miért? Minden megnyilvánulásuk mögött a magyar haza szeretete, a magyar faj szupremáciájának szolgálata áll. Nem klerikálisok, csak szeretik saját vallásukat, csak akkor vannak a liberalizmus ellen, ha azt önérdek-érvényesítésre használják, nem antiszemiták, csak ráébresztették az ifjúságot a magyar fennhatóság (szupremácia) fontosságára a magyar hazában, ami szerintük természetes, s arra, hogy az Egyetemi Körben is magyar kézben kell legyen a vezetés. Ebben a munkában nagyon sok olyan zsidó polgártárs segítette őket, akik felismerték, hogy amely államban a nemzetalkotó fajt leszorítják, az az állam elpusztul. Az antiszemitizmust tehát nem ők csinálják, hanem a sajtó, amikor az ő hazaszeretetüket úgy magyarázza, hogy az antiszemitizmus. ${ }^{27}$

A konzervatív irányítású Egyetemi Kör ellen ebben az időszakban ugyanis a fővárosi liberális hírlapok folyamatosan az antiszemitizmus vádját hangoztatták, az egyetemi pártokat pedig a politikai pártok mintájára liberálisnak, illetve konzervatívnak, néppártias színezetűnek nevezték. Ezzel meghatározták az ország távolabbi vidékein más felsőoktatási intézmények diákegyesületeinek véleményét, például a kolozsváriak vagy a sárospatakiak ítéleteit. A kolozsvári Egyetemi Kör antiszemitának nyilvánította a budapesti Egyetemi Kör vezetésének irányvonalát. A kolozsvári Egyetemi Kör mintegy a budapesti Egyetemi Kör ellenzékeként működött. ${ }^{28} \mathrm{~A}$ budapestiek védekeztek: szerintük Kolozsváron csak a hírlapokból értesülnek a budapesti eseményekről, és fogalmuk sincs a budapesti speciális viszonyokról. Nem értik, illetve félreértik a budapesti egyetemi ifjúság reakcióit, mivel sehol nem olyanok a társadalmi-nemzetiségi viszonyok, mint a fóvárosban, ahol a zsidó hallgatók összpontosulnak és vezető szerepre törnek. Kolozsvá-

${ }^{25}$ Egyetemi Lapok X. évf. (1896. április 30.) 12. sz., 5-6.

${ }^{26}$ Egyetemi Lapok X. évf. (1896. február 5.) 4. sz., 8.

27 Egyetemi Lapok XI. évf. (1896. november 10.) 3. sz., 1-2.

${ }^{28}$ Egyetemi Lapok X. évf. (1896. április 10.) 10. sz., 8-9. 
ron nem kellett viszonyuljanak asszimilálódó zsidó diáktársaik olyan tömegéhez, mint a budapesti egyetemen, az ottani asszimilálódott zsidó hallgatók, kevesen lévén, nem fogalmaztak meg önálló csoportérdekeket, és belesimultak az egyetemi társadalomba. A kolozsváriak számára a budapesti ellentétek pusztán felekezeti problémaként jelentek meg, és nem értették azokat az árnyalatokat, amelyeket a budapestiek éreztek, hanem a Mózes-vallású magyarokat ugyanolyan magyaroknak tartották, mint saját magukat. Ilyen értelemben a „felvilágosult” szellemű magyar ifuúság táborát gyarapították.

Támadás érte a budapesti Egyetemi Kört Debrecenből is, a Debreceni Főiskolai Lapok szerint nem tölt be vezérszerepet a vidéki akadémiák ifjúsága fölött, nem teremt egységes diákközéletet és érintkezést. Nincs ideje az országos diákügyekkel foglalkozni, mert lefoglalják saját ügyei: tagjainak érdekei, az áldatlan párttusák. Budapest elismerte, hogy egyedül a diákkongresszusokon találkoznak a vidéki ifjúsággal, ahol hoznak ugyan határozatokat, de ezek foganatosítása már nem történik meg. ${ }^{29}$

Wolfner Pál az egyetemi antiszemitizmus nemlétéről ír. Rögtön megvallja zsidó voltát, hogy ne legyen antiszemitizmussal vádolható. Azt állítja ugyanis, hogy az antiszemitizmust az egyetemen maguk a zsidók csinálják, illetve nem az összes zsidó, csak az a töredék, akiket kiszorítottak a szereplésből. Ők a párt érdekét kiterjesztették az egész hitfelekezetre, azt állítva, „ha győz az ellenpárt, a zsidóság elveszett”. Az ilyen mindig válaszlépést szül. Wolfner tanácsa az, hogy a következő választásoknál ne tömörüljenek a zsidók egy pártba, és ne így akarják kivívni ún. érdekeiket, hanem egyénként érvényesüljenek bármilyen pártban. A jelenlegi helyzet kedvező erre, mert ismerve a viszonyokat, kijelentheti, hogy ma egy párt sem vall antiszemita elveket. ${ }^{30}$

Az 1897/98-as tanév átmenetinek tekinthető abban az értelemben, hogy Ortmann Albertet, a konzervatív párt elnökét választják meg a kör elnökévé, de az uralmon levő párt cselekvésképtelen és tehetetlen. Ugyan soha ilyen látogatott, mozgalmas nem volt az Egyetemi Kör, amelynek ekkor 1200 tagja van, de a programokat nem a konzervatív párt szervezte. Az Egyetemi Kör évzáró közgyűlésén az ellenzéki párti Zsembery Gyula alelnök által elmondott beszédből többet tudunk meg a kör éves tevékenységéről, mint a lap cikkeiből. A bizottság működését az első félévben a pártküzdelmek dominálták, de míg a kormányrúdnál lévő pártot a védekezés teljesen igénybe vette, addig az ellenzék dolgozott. Sikeresen vezette a szakosztályok életét, megalakította a karok fölötti Általános Egyetemi Segélyegyletet, és népszerű jótékonysági matinét szervezett jeles művészek és a társadalom előkelőségei részvételével. ${ }^{31}$

Mind jobban előtérbe kerül az egyetemi iffúság szociális helyzete. Az ezzel kapcsolatos írások növekvő száma is mutatja, hogy felismerték, hogy ezzel a kérdéssel foglalkozni kell, keresni kell rá a megoldást. Herczeg Mihály rektor írja cikkében, hogy a szocialisták újabban a szegény sorsú egyetemi ifjúságból toborozzák híveiket. Ezt nem

${ }^{29}$ Egyetemi Lapok XI. évf. (1897) 5. (11.) sz., 2-3.

${ }^{30}$ Egyetemi Lapok XI. évf. (1897) 8. (14.) sz., 8.

${ }^{31}$ Egyetemi Lapok XII. évf. (1898. június 18.) 20. sz., 2-5. 
lehet tétlenül nézni, segíteni kell a nép fiaiból kiemelkedett egyetemi hallgatóknak, hogy befejezhessék tanulmányaikat, ne zülljenek el, ne maradjanak féltudósok, szellemi proletárok, mert ezek a társadalom legveszedelmesebb elemei. A vagyonos osztálynak kell tudomásul vennie, hogy kötelessége a segítségnyújtás. Elsősorban munkalehetőséggel segítsenek, olyannal, ami nem vonja el nagyon a segített hallgatókat az egyetemi előadások látogatásától. ${ }^{32}$

A tanév közepén, a II. félévtől most már rektori utasításra, békebíróság közbenjárására békült ki és kötelezte magát együttműködésre a két párt. Ebben a félévben úgy müködtek együtt, hogy a vezetés színleg a konzervatív párt kezében volt, de ténylegesen az agilisabb liberális zsidó párt kezében, amely reformpárt néven lépett fel és sikeresen szervezte meg az Egyetemi Kör életét.

A következő év, az 1898/99-es tanév egyetemi választásait pedig a reformpárt ellenpárt nélkül (amely teljesen szétesett) nyerte meg, üdvözölte őt a kolozsvári Egyetemi Kör és az ország több akadémiájának ifuúsági egyesülete, akik nagy reményeket füztek a reformpárt vezetéséhez. A reformpárt elnöke, Szemenyei Kornél programjában a köri élet teljes reformját hirdette meg: 1 . Fontos a társadalmi csiszoltság, vagyis minél gyakrabban matinékat, társas összejöveteleket szervezni, hogy a társadalommal folyamatos érintkezésben álljanak. 2. Fontos az ép testben ép lélek, tehát a sportélet fejlesztése, hogy az ifjúság kellő ellenállást fejtsen ki a hanyatló, dekadens életmóddal szemben. 3. Az egységben van az erő. Mindent meg kell tenni az ifúság egységbe tömörítéséért, mert csak egy egységes ifuúság játszhat jelentékeny szerepet a társadalomban, közéletben egyaránt. Ki kell küszöbölni mindazt, ami eddig szétválasztotta az ifuúságot, így a politikai és felekezeti jelszavakat is. ${ }^{33} \mathrm{Ez}$ a program egy nagypolgári, az anyagi nehézségeket nem ismerő ifjú életmódjához illő, a társadalmi életbe való beilleszkedést, a kapcsolattartást, a mértékletességet szem előtt tartó sikeres életmód racionális megtervezése. A program a hasonló életmódú ifjak körének való, egy bizonyos társadalmi kör osztálynézőpontjából láttatja a világot, amelyből az egyetemen tanuló ifjúság nagy többsége anyagi helyzete miatt ki volt zárva.

Az új vezetés nagy lendülete a tanév közepére azonban megtorpant, Szemenyei Kornél egészségügyi okokból lemondott, az elnöki székben Ludwig Rezső követte. Olyan hangok hallatszottak, hogy a reformpárt, amely füt-fát ígért, most, hogy uralomra jutott, nem tesz semmit, csak tétlenül élvezi a dicsőséget. Keresték az okokat, amiért az ifú́sági élet pang, a kör tagjai nagyon kevesen, kb. 300-an voltak. ${ }^{34}$

Miután a reformpárt helyet adott egy aktuálpolitikai eseménnyel - az ex lex állapot ellenzése - kapcsolatos ülésnek, 1899. január 7-én az Egyetemi Tanács bezáratta a kört. Erre írta meg Ady Endre a Debreceni Főiskolai Lapok munkatársaként (3. éves joghallgató) hírhedt cikkét a budapesti Egyetemi Körről, amely elpolitizálta a Diákszövetség

32 Egyetemi Lapok XII. évf. (1897. november 1.) 4. sz., 7-8.

${ }^{33}$ Egyetemi Lapok XIII. évf. (1898. október 1.) 1. sz., 4-5.

${ }^{34}$ Egyetemi Lapok XIII. évf. (1899. január 1.) 7. sz., 1-2. 
ügyét. ${ }^{35}$ Olyan szuggesztív az írása, hogy az egész ország ifjúsága, nem ismerve belülről az ügyet, ebből formál véleményt. Olyan gunyorosan ír Ludwigh Rezső programjának fó pontjáról, a teaestélyek rendezéséről, hogy bárhogy magyarázkodjék a reformpárt, napjai meg vannak számlálva. Februárban Ludwig Rezső lemondott. Bár leszállították felére a tagdíjat, még sincs elég tagja a körnek. Az egyetemmel szemben új helyiséget vett ki a kör, ahol reményei szerint élénkebb lesz a társasági élet - ez az Egyetem tér 5. szám alatti, az Egyetemi templommal átellenben lévő sarki épület, Andrássy Géza bérpalotája ${ }^{36}$ Mindennek ellenére a köri élet vegetál, megszűnik az érintkezés a vezetők és az ifjúság nagy tömege között. A politizálásból kiábrándult és a tudományos munka terén elérhető sikerekbe menekülő zsidó egyetemi vezető ifjak megalakították a Joghallgatók Tudományos Egyesületét, hasonlóképpen megalakult a BEAC. E két tartósan fennálló, nagy sikerű intézmény alapítása maradt a reformpárt regnálásának eredménye. Év végére a reformpárt megszünt.

Hogy miért végződött ilyen szomorúan a nagy reménnyel induló párt sorsa, annak oka abban keresendő, hogy vezetői megtapasztalták, hogy zsidóként nem lehetnek az egész iffúság vezetői, mert ezt a vezetést a magyar ifjak nem ismerik el. Addig volt virágzó a köri élet, amíg kettős kézben volt a vezetés: az élén magyarok álltak, „mintegy” cégéreként az egyesületnek, és a gyakorlati életben a szervezés a zsidó származásúak kezében volt. Az eset nagyon jó példája a magyar középosztály kettőssé válása folyamatának: az asszimilálódott zsidó származásúak belátták, hogy a befogadó társadalom - az, amely ugyanakkor emancipálta őket - mégis számon tartja azt, hogy ők „újonnan lett” magyarok, tehát hiába a nyelv, a szokások, sokszor még a vallás felvétele is, ugyanolyan történelmi múlt híján érzelmileg mégsem lehetnek ugyanolyan „magyarok”, akiknek a vezetését el lehet fogadni. A vereség feldolgozása ugyanakkor önreflexióra és magukkal való számvetésre késztette ezeket a tehetséges zsidó ifjakat. A zsidó származású hallgatók különböző válaszokat adtak, amelyek a közeledni akarókat még közelebb hozták a magyarság megértéséhez, másik részüket viszont eltávolította, és ennek következményeként úgy gondolták, hogy nekik kell megreformálni a magyar társadalom gondolkodását.

35 Debreceni Főiskolai Lapok (1899. január 20.) 5. sz., 59-60.

36 Az Egyetemi Kör új otthonának megnyitó ünnepségét a következő tanév, az 1899/1900-as tanév decemberében tartották, amelyen Wlassics Gyula kultuszminiszter is részt vett. Budapesti Hírlap, 1899. december 15., 6. 